\title{
Corporate Capital Structure and Corporate Market Value: Empirical Evidence from Nigeria
}

\author{
Oboh Sankay Collins ${ }^{1}$, Isa Envulu Filibus ${ }^{2} \&$ Adekoya Adeleke Clement ${ }^{1}$ \\ ${ }^{1}$ Department of Accounting, University of Lagos, Nigeria \\ ${ }^{2}$ Department of Accounting, Nasarawa State University Keffi, Nigeria \\ Correspondence: Oboh Sankay Collins, No. 80 Ogunlana Drive, Surulere, Lagos, Nigeria. Tel: \\ 234-80-6956-1340. E-mail: colsanky@yahoo.com
}

Received: August 7, $2012 \quad$ Accepted: October 18, $2012 \quad$ Online Published: November 4, 2012

doi:10.5539/ijef.v4n12p193 URL: http://dx.doi.org/10.5539/ijef.v4n12p193

\begin{abstract}
Within the context of the Modigliani-Miller relevance theory and the static order theory of capital structure, this paper empirically examined the effect of a firm's capital structure on its market value. Dataset from 39 non-financial listed companies for the period of 2005-2009 were used for analysis. Results from the regression analysis show a significant and positive relationship between non-financial firms' market values and their debt-equity ratios. Whereas, a negative relationship exists between a firm's total-debt/total-capital ratio and its market value, its size positively affects its market value. Hence, we conclude that firms' leverage positively influence their market values. Suggesting that, a firm can actually attain an optimal capital structure.
\end{abstract}

Keywords: capital structure, market value, non-financial firms, static order theory, size

\section{Introduction}

During the last decade, series of considerable debates have emerged, both theoretically and in empirical researches on the effects a firm's choice of capital structure have on its market value. Series of questions such as what capital mix seems to optimize a firm's market value, what role does debt capital play in the capital structure and what factors influence a firm's choice of capital structure are yet to receive realistic answers. This has made the capital structure proposition a difficult puzzle to unravel. Major debates have centred on the existence of an optimal capital structure and the level of debt usage relevant to individual firm's capital structure. Following the Modigliani-Miller paradigm in 1958, corporate financing decision preference has attracted the attention of most scholars of corporate finance in the past decades which has stimulated substantial research efforts in determining what seems to be an optimal capital structure for firms as it affects corporate market value within the corporate cycle.

According to Modigliani and Miller (1958), under the perfect capital market assumption, a firm's market value does not depend on its choice of capital structure when there are no bankruptcy costs, taxes, and capital markets are frictionless. But after due consideration on the inclusion of corporate taxes, Modigliani and Miller (1963) assented, by way of amending their previous proposition, that when there are corporate taxes then interest payments are tax deductible and that 100 percent debt financing is optimal. That is, corporate value increases as debts increases. Considering this argument, despite the substantial research efforts devoted in determining an optimal capital structure for individual firms, there is still no generally accepted theory throughout the literatures explaining the debt-equity choice of firms (Adeyemi and Oboh, 2011). But in the last decades, several theories have emerged explaining firms' capital structure and the resultant effects on their market values such as the pecking-order theory, the static-order theory and the agency cost theory among others (Bokpin and Isshaq, 2008). Although the arguments for the existence of an optimum capital structure have not gained a universal acceptance, lot of empirical discoveries and suggestions point to the fact that an optimum capital structure for individual firms exist (Wippen, 1966; Ozkan, 2001).

In Nigeria, one of the fundamental causes of corporate distress points to the fact that inadequate capital and inappropriate capital mix characterize the Nigeria firms (Salawu, 2007). Generally, firms are faced with a complex list of options when deciding on their choice of capital structure. Most firms have to choose either to finance their investments with retained earnings, new equity issues, or through debt. However, it has been 
observed that the Nigerian firms most often use equity rather than debt in financing projects (Adeyemi and Oboh, 2011) as compared to firms in the developed nations. According to Bolton and Scharfstein (1996), in their observation of firms in the U.S. for the period of 946 to 1987 discovered that external financing through debt issues amounted to about $85 \%$ as compared to $7 \%$ through equity.

Notwithstanding, Bhaduri (2002) discovered that most emerging economies not until lately little value the important roles companies play in economic growth and national development and, that companies in these nations encounter various limitations on their decisions concerning sources of finance. Also, the underdeveloped nature of the stock markets in these nations has made access to funds quite difficult. Furthermore, Guha-Khasnobis and Kar (2006) discovered that over-dependence on governmental sources of finance has really mired the development of both the equity and debt markets in most emerging economies. Nevertheless, there have been substantial operational changes in the Nigerian stock market since the 2005 capital base restructuring in the banking industry. These have significantly enhanced the flexibility of most firms in deciding their capital mix optimally. However, the debt market as in many other undeveloped economies is still inefficiently developed (Salawu, 2007; Adeyemi and Oboh, 2011).

The aim of this study is to facilitate an optimal capital structure for firms in the third world nations. This is because empirical evidences have shown that a firm's capital structure is fundamental in determining its going concern in times of economic instability and financial distresses. This paper make up for the paucity of scholarly papers as only few studies have attempted examining the capital structure dynamics in third world nations. It also adds to the literature by providing empirical evidence within the context of the Modigliani-Miller relevance theory and the static-order theory the effects of a firm's choice of debt-equity mix on its market value drawing evidence from Nigeria. To the best of our knowledge, there are only few studies in Nigeria that have examined the Nigerian milieu of corporate capital structure as it affects market values, and still with no consensus consideration.

The other parts of the paper are arranged as follows: the second part reviews the related literature, while the third part is on methods used. The result and discussion, and conclusion of the study followed in the fourth and fifth part respectively.

\section{Literature Review and Theoretical Framework}

According to Salawu and Agboola (2008), research efforts into firms' financing decisions have been minimal in the third world nations. Most studies only report findings for firms in the industrialized nations. In the argument of Errunza (1979), when a study is conducted elsewhere, especially in the developed nations, it is important to note that in reality most assumptions such as the perfect capital markets often do not exist in most developing nations. Also, he argued that most nations would rarely adapt to the contemporary theories of capital markets founded on these suppositions because different nations have divergent legislative provisions, primarily with regards to corporate market regulations, economic growth level, bankruptcy and tax laws and the roles financial institutions play. These factors also contribute to the variation and divergence of corporate capital structure across nations.

A firm's capital structure as discussed by Inanga and Ajayi (1999) could be described as the capital mix of debt and equity in financing its assets. Simply put, it is the relative portion of a firm's equity, debt and other long term securities, combined together to finance its long term investments in its assets. Therefore, it is imperative to note that the capital structure theory has a close relationship with the cost of capital of the firm and, that the primary objective of the capital structure decisions is to aid a firm in achieving its financial objectives through an optimal mix of long-term sources of finance. By this optimal capital structure, the firm's total cost of capital is minimized. Nevertheless, it still remains an unraveled argument whether individual firms could attain an optimal capital structure or not. According to Besley and Brigham (2000) and Ross et al. (2002), major arguments have centered on the actuality of a firm affecting its value and cost of capital by fluctuating its capital mix. Harris and Raviv (1991) argued that the evaluation of the capital structure of companies is imperative because, not only does it affect a firm's market value but that it also affects its real decisions about employment, production, and investment.

Although there have been substantial research efforts devoted by different scholars in examining the factors affecting a firm's choice of capital structure, no generally accepted theory exist throughout the literatures explaining the firm's choice of debt-equity combination. But in the last decades, there are several theories propounded explaining a firm's capital structure and its determinants subsequent to the Modigliani-Miller (1958) paradigm. Different scholars have expanded on their irrelevance theory of capital structure and several theories have emerged explaining the capital structure choice of a firm and the factors influencing such choice. For 
instance, the pecking-order theory, the static-order theory and the agency cost theory among others have been largely discussed in the literatures (Bokpin and Isshaq, 2008).

In the irrelevance theory of capital structure as postulated by Modigliani and Miller (1958), a firm's value depends on its operating profitability rather than its capital structure under perfect capital market conditions; that is, value irrelevant (Modigliani and Miller, 1958). But, in their second proposition, they argued that market value is an increasing function of a firm's leverage when an interest payment is permitted by the tax law (Modigliani and Miller, 1963). This theory despite its success raised a number of considerable debates among researchers (Modigliani and Miller, 1963; Baxter, 1967; Warner, 1977; Miller, 1977; DeAngelo and Masulis, 1980; Altman, 1984; Myers, 1984; Leland, 1994; Abu, 2008).

The agency cost theory on the other hand according to Jensen and Meckling (1976) states that optimal capital structure is obtained when the costs of conflicts between the principal and the agents are minimized. This theory also supports that a firm can actually attain an optimal capital structure by its choice of capital mix. Thus, suggesting that the choice of a firm's capital structure is vital in maximizing its value as supported by the static trade off theory. However, Smith and Warner (1979) stated that the basis of the firm's capital mix necessarily does not influence agency cost, for superfluous bonuses, asset changeover, high-ranking debt issuance and underinvestment are what constitute agency cost of debt problem. By this, it shows a prediction that growing firms should make use of less debt. Thus, suggesting a possible relationship between the market value of a firm and its choice of capital mix. Extension of this theory could be seen in Myers (1977), Jensen (1986), Hart and Moore (1988) and Parrino and Weisbach (1999).

While the static-order theory according to Baxter (1967) and Altman (1984) suggests that where the net-tax benefit of debt capital weighs leverage associated costs, optimal capital structure is obtained. According to Ahmed and Hisham (2009), different questions have been asked with regard to the increase tax-shield advantage arising from debt issue and if it may compensate for distress costs such as likely bankruptcy cost and competitive risk when pressured for cash. With regard to this theory, when new equity issues are made, the firm's capital structure deviates from optimum level. However, this should be seen as undesirable. Myers (1984) suggested that assuming this theory, may possibly be considered as setting a debt-to-value objective ratio with a continuing effort to attain it. Though, he argued that when managers perceived the stock price is undervalued in the market, they will be unwilling to make equity issues. And when this happens, the investors only recognize that issuance of equity only occurs when it is either justly priced or high-priced. Consequently, investors are most likely to adversely respond to equity issues and management will be unwilling to make new issues. This model of capital structure has been extensively discussed and extended by other scholars (see Miller, 1977; DeAngelo and Masulis, 1980; Bradley et al., 1984; Titman and Wesels, 1988; Barclay and Smith, 1999; Fama and French, 2002). This theory also suggests that bigger and more matured companies make use of more debt than equity in their capital structure.

After the Modigliani-Miller (1958) prediction on the capital structure decision, the pecking-order theory was introduced by Donaldson (1961) in sharp contrast to the capital structure irrelevance theory as put forward by Modigliani and Miller (1958). This theory is among the most influential theories of corporate leverage. It goes contrary to the idea of firms having a unique combination of debt and equity finance, which minimize their cost of capital. It suggests that when a firm is looking to finance its long-term investments, it has a well-defined order of preference with respect to the sources of finance it uses. It states that a firm's first preference should be the utilization of internal funds (i.e. retained earnings), followed by debt and then external equity. He argued that the more profitable firms become, the lesser they borrow because they would have sufficient internal finance to undertake their investment projects. He further argued that it is when the internal finance is inadequate that a firm should source for external finance and most preferably bank borrowings or corporate bonds. And after exhausting both internal and bank borrowing and corporate bonds, the final and least preferred source of finance is to issue new equity capital. Other researchers have reacted to this theory (see Myers, 1984; Shyam-Sunder and Myers, 1999; Fama and French, 2002). This theory as postulated by Donaldson (1961) does not support the idea of a firm's choice of capital structure being affecting by any factor, rather, it suggests that a firm should follow a well-defined order of financing its investments regardless of any factor.

This paper however, in the context of the Modigliani-Miller relevance theory and the static order theory of capital structure discusses how a firm's capital mix affects its market value. Normally firms finance their operations through various sources consisting of preferred shares and debts, variable and secure income securities. Therefore, corporate financing decision simply involves a firm combining various securities in order to minimize its risks and maximize expected returns. The essential argument here is how a firm should strike a balance between risk and return in order to attain optimum capital mix of debt and equity. A firm's capital 
structure could either be all equity financed (i.e. 100\% equity capital), or all debt financed (i.e. 100\% debt capital), or could be an appropriate mix of both equity capital and debt capital (i.e. X\% equity capital and Y\% debt capital).

\section{Data and Methodology}

\subsection{Empirical Model and Estimation Method}

In this study, we tested the empirical effect a firm's capital structure has on its market value using a multiple regression estimator framework. By way of a purposeful sampling technique, dataset were obtained from the annual reports and accounts of a selection of 39 listed non-financial companies out of 186 for the period of 2005 to 2009. The sample size was determined based on data availability, because in the process of data collection, it was observed that most Nigerian non-financial firms scarcely make use of long-term debt in their capital structure. Periodical publications of the Nigerian Stock Exchange such as fact books were also depended upon to augment available data. Seeing that some of the variables in this study are proxies for the real variables, it is imperative at this point to properly define the constructed variables. The regression model states:

$$
M K T-V A L=\alpha_{0}+\alpha_{1} L E V(1)+\alpha_{2} L E V(2)+\alpha_{3} S I Z E+\varepsilon \ldots \ldots .
$$

Where:

$M K T-V A L=$ market price per share (being the dependent variable);

$L E V(1)=$ long-term debt/equity capital;

$\operatorname{LEV}(2)=$ total-debt/total capital;

SIZE = natural logarithm of net assets;

$\alpha 0=$ Intercept or constant of the equation;

$\alpha 1, \alpha 2, \alpha 3=$ as coefficients of the independent variables; and

$\varepsilon=$ error term

\subsection{Variables and Measures}

The key variables of this study include the market value of the firms, their debt-equity mix (Lev 1) and total-debt/total capital ratio (Lev 2) for the specified financial period. According to most corporate finance literatures and theories of capital structure, the firms' debt ratios (DRs) are usually used as the measurement for the level of leverage employed by the firms. This largely depends on the purpose the study seeks to achieve. Prior empirical studies have employed a broad choice of debt ratios as measurement for financial leverage (see Hamson, 1992; Abu, 2008). For the purpose of this study, their debt-equity mix (Lev 1) and total-debt/total capital (Lev 2) were used to measure their DRs. The MPPS, on like prior studies, has been used in this study because, most firms are generally valued based on their market values in times of takeover or merger, and or, when a new issue is to be made. And also, most investors are likely to be attracted to firms with higher MPPS than those with lower MPPS. Furthermore, the size of the firms has been included in the regression analysis as a control variable in order to bring the study to a logical conclusion. Different measurements for firm size have been employed in most prior empirical studies. For instance, Hamson (1992) used the natural logarithm of the sum of the fair value of equity and the book value of liabilities, the natural logarithm of total-assets has been employed by Gul and Tsui (1998) and the natural logarithm of sales as used by Titman and Wessels (1988). However, this study adopted the natural logarithm of net-assets as the measurement for the firms' size.

\section{Empirical Results and Discussion}

\subsection{Descriptive Analysis}

In this section, we examined the descriptive statistics for both the explanatory and dependent variables of interest. Each variable is examined based on the mean, standard deviation and normally distributed skewness and kurtosis values. A long right tail signifies a positive skewness and a long left tail signifies a negative skewness. A value of 3 has been suggested to be a normal kurtosis value. A variable with a value greater than 3 indicates a substantial peak. But when it is less than 3, then the distribution will be flatter. Table 1 below displays the descriptive statistics for the study. 
Table 1. Descriptive statistics

\begin{tabular}{lrrrrrrr}
\hline Variables & Min & Max & Mean & Std. D & Skewness & Kurtosis & N \\
\hline Dependent: & & & & & & & \\
MKT-VAL & 1.398 & 225.934 & 28.8053 & 48.8269 & 2.858 & 8.362 & 39 \\
Independent: & & & & & & & \\
LEV(1) & 0.0009 & 1.9849 & 0.3866 & 0.4087 & 2.224 & 6.059 & 39 \\
LEV(2) & 0.0009 & 10.1322 & 0.4653 & 1.5962 & 6.152 & 38.203 & 39 \\
SIZE & 4.68 & 7.60 & 6.5174 & 0.7001 & -0.629 & 0.137 & 39 \\
\hline
\end{tabular}

Note. This table presents descriptive statistics for all the variables of interest

As shown in Table 1, the mean value for MKT-VAL indicates that, on the average, most non-financial firms have a relatively fair market value $($ mean $=28.8053)$. That is, not too low and not too high, suggesting that only a few firms have their market values above average. The mean value for $L E V$ (1) signifies that on the average, the debt/equity ratios of most firms are skewed towards equity capital than debt capital (mean $=0.3866$ ). Implying that, most non-financial firms in Nigeria are low-geared companies. Whereas the mean value for $L E V$ (2) indicates that the total debt/total capital ratio of most of the firms is below average (mean $=0.4653$ ), the mean value for SIZE indicates that most of the firms are large companies having their net assets above average (mean $=6.5174)$.

Furthermore, considering the $M K T-V A L$ variable, it shows a right tail distribution (skewness $=2.858$ ), as well as a substantial peak value (kurtosis $=8.362$ ). Also, the $L E V(1)$ and $L E V(2)$ variables show right tail distributions as seen in Table 1 (skewness $=2.224$ and 6.152 respectively) and substantial peak values (kurtosis $=6.059$ and 38.203 respectively). Whereas, the SIZE variable has a left tail distribution and a low peak value (skewness = -0.629 and kurtosis $=0.137$ respectively). From the descriptive statistics as a whole, the variables show right tailed distributions and substantial peak values, except for the SIZE variable which shows a left tail and low peak value. We therefore conclude that variables are skewed and have substantial kurtosis values.

\subsection{Correlation Analysis}

As part of the procedure for analysis in this study, a correlation analysis was performed in order to establish relationship among all the variables of interest. Table 2 below displays the correlation matrix.

Table 2. Correlations Matrix

\begin{tabular}{|c|c|c|c|c|c|}
\hline & & MKT-VAL & LEV(1) & LEV(2) & SIZE \\
\hline \multirow[t]{2}{*}{ MKT-VAL } & Pearson Correlation & 1 & & & \\
\hline & Sig. (2-tailed) & & & & \\
\hline \multirow[t]{2}{*}{$\operatorname{LEV}(1)$} & Pearson Correlation & $.392(*)$ & 1 & & \\
\hline & Sig. (2-tailed) & .014 & & & \\
\hline \multirow[t]{2}{*}{$\operatorname{LEV}(2)$} & Pearson Correlation & -.042 & .205 & 1 & \\
\hline & Sig. (2-tailed) & .801 & .211 & & \\
\hline \multirow[t]{2}{*}{ SIZE } & Pearson Correlation & $.443(* *)$ & .252 & -.023 & \\
\hline & Sig. (2-tailed) & .005 & .122 & .889 & \\
\hline
\end{tabular}

Note: *Significant at $5 \%$ level (2-tailed), $\quad * *$ Significant at $1 \%$ level (2-tailed). $N=39$

An examination of Table 2 shows that the highest correlated variable of the MKT-VAL is the SIZE variable, having a correlation coefficient of 0.443 and it is significant at a 0.005 level of significance $(\mathrm{P}<0.01)$. While the next correlated variable to the $M K T-V A L$ variable is the $L E V$ (1) with a correlation coefficient of 0.392 and significant at a 0.014 level of significance $(\mathrm{P}<0.05)$, while $L E V(2)$ has a negative correlation coefficient of -0.042 and not significant $(\mathrm{P}=0.801)$. Analysis among the independent variables shows that there are no correlations among them. Hence, indicating that there is an absence of multicollinearity. With regards to the correlation analysis, we conclude that larger non-financial firms tend to have higher market values than smaller firms. Whereas the capital-mix of long-term debt and equity capital has a positive influence on the firms' market value, their total debt (combination of long and short term debts) to total capital has a negative impact on their market value. 


\subsection{Regression Analysis}

This study primarily examined the empirical effect a firm's debt-equity choice has on its value. In order to evaluate this effect, this study adopted the multiple regression estimation analysis and the regression results of the model are given in Table 3 below.

Table 3. Regression Analysis

\begin{tabular}{lccccc}
\hline & Predictors' Variables & Constant & LEV(1) & LEV(2) & SIZE \\
\hline $\begin{array}{l}\text { Dependent Variable } \\
\text { (MKT-VAL) }\end{array}$ & 0.032 & 0.040 & 0.501 & 0.020 \\
& & $(-148.047)^{\mathrm{a}}$ & $(38.435)^{\mathrm{a}}$ & $(-3.040)^{\mathrm{a}}$ & $(25.072)^{\mathrm{a}}$ \\
& & $-2.238^{* *}$ & $2.133^{* *}$ & -0.681 & $2.434^{* *}$ \\
\hline F-statistics & 4.753 & R-square & & 0.289 \\
Sig. of F-statistics & 0.007 & Adj. R-square & & 0.229 \\
No. of sample & 39 & Dur-Wat. & & 2.040 \\
\hline
\end{tabular}

**Note: Significant at $5 \%$ level and ${ }^{\text {a }}$ coefficients are in parenthesis.

As shown in Table 3, the results from the multiple regression analysis reported the F-statistic to be 4.753 and being statistically significant at a 0.007 level $(\mathrm{P}<0.05)$. The $\mathrm{R}^{2}$ and adjusted $\mathrm{R}^{2}$ values are indicated as 0.289 and 0.229 respectively. The Adj- $\mathrm{R}^{2}$ value shows that the estimated model is able to explain about $23 \%$ of the variations in firm value. While the Durbin Watson test shows a value of 2.040. Examining the regression coefficients of the model, $L E V(1)$ has a coefficient value of 38.435 and positively significant at 0.040 level $(\mathrm{P}<$ $0.05), L E V(2)$ has a negative coefficient of -3.040 and not statistically significant $(\mathrm{P}=0.508)$, while SIZE has a coefficient of 25.072 and a significant value of 0.020 level (i.e. $\mathrm{P}<0.05$ ). Based on the regression analysis as shown in Table 3, we conclude that a positive and significant relationship exists between a firm's market value and its debt-equity choice and size. In conformity with the M\&M and static-order theoretical standpoints, Table 3 plainly demonstrations that a firm's market value increases as a result of the increase in its financial leverage since the expected coefficient for $L E V$ (1) is positive. However, the level of its total-debt to total capital ratio should be adequately managed so as to minimize debt associated risk. The estimate for the SIZE simply suggests that bigger companies have higher market value for every unit of investment. Hence, supporting the argument for investment diversification and economies of scale in leverage related costs (Abu, 2008).

Furthermore, in order to find out the autocorrelation in the residuals in the regression, the Durbin-Watson (DW) value of model was computed. The result shows the value of 2.040, implying that the independence of residuals assumption is not violated. This conclusion is based on the suggestion of Kohler (1994), stating that the Durbin Watson values have an upper limit of 4 and lower limit of zero. So, if the Durbin-Watson value is equal to 2, then there exists no autocorrelation, but if the value is less than or greater than 2 , then there exists a positive correlation or negative correlation respectively. Also, it was observed from the analyses, that most non-financial firms in Nigeria scarcely make use of debt capital in their capital structure, thereby making their capital structure lopsided. That is, more equity capital to debt. It was also observed that the firms' debt structure is mostly dominated by short-term debts. One of the reasons identified for the inappropriate capital mix is due to the lack of theoretical background on the part of the financial managers.

\section{Conclusion}

After the seminal Modigliani-Miller paradigm on the theory of capital structure and the effects on market value in 1958, major debates have centred on the existence of an optimal capital structure and the level of debt usage relevant to individual firm's capital structure. Therefore, for this discrepancy in theory that this study attempted to empirically investigate how a firm's choice of capital structure affects its market valuation, basing its argument on the Modigliani-Miller relevance theory and the static order theory of capital structure. Consistent with prior empirical studies, we conclude that a firm's leverage choice affects its market value positively and significantly. Suggesting that, a firm can actually attain an optimal capital structure, where its risk will be minimized and returns maximized. This is in support of the research findings of Modigliani and Miller (1963) and Abu (2008) among others, but in sharp contrast to the pecking order theory as propounded by Donaldson (1961), which assumes a firm's capital structure as irrelevant to its market value and that a firm's choice of capital structure should follow a well-defined order. 


\section{References}

Abu, M. T. (2008). Capital structure choice and the firm value in Australia: a panel data analysis under the imputation tax system. Advances in Quantitative Analysis of Finance \& Accounting, 6, 205-237. http://dx.doi.org/10.1142/9789812791696_0011

Adeyemi, S. B., \& Oboh, C. S. (2011). Perceived Relationship between Corporate Capital Structure and Firm Value in Nigeria. International Journal of Business and Social Science, 2(19), 131-143.

Ahmed, H. J. A., \& Hisham, N. (2009). Revisiting Capital Structure Theory: A Test of Pecking Order and Static Order Trade-of Model from Malaysian Capital Market. International Research Journal of Finance and Economics, 30, 58-65.

Altman, E. (1984). A further empirical investigation of the bankruptcy cost question. The Journal of Finance, 39(4), 1067-1089.

Barclay, M. J., \& Smith, C. W. (1999). The Capital structure puzzle: another look at the evidence. Journal of Applied Corporate Finance, 12(1), 8-20. http://dx.doi.org/10.1111/j.1745-6622.1999.tb00655.x

Baxter, D. (1967). Leverage, Risk of ruin and the Cost of capital. Journal of Finance, 22(3), 395-403.

Besley, S., \& Brigham, E. F. (2000). Essentials of managerial finance $\left(12^{\text {th }}\right.$ ed.). USA: The Dryden press, 458.

Bhaduri, S. N. (2002). Determinants of capital structure choice: A study of the Indian corporate sector. Applied Financial Economics, 12(9), 655-665. http://dx.doi.org/10.1080/09603100010017705

Bokpin, A. G., \& Isshaq, Z. (2008). Stock market development and financing decisions of listed firms in Ghana. African Journal of Business Management, 2(11), 209-216.

Bolton, P., \& Scharfstein, D. S. (1996). Optimal debt structure and the number of creditors. The Journal of Political Economy, 104(1), 1-25. http://dx.doi.org/10.1086/262015

Bowman, J. (1980). The importance of a market value measurement of debt in assessing leverage. Journal of Accounting Research, 18, 242-252. http://dx.doi.org/10.2307/2490400

Bradley, M., Jarrell, G. A., \& Kim, E. H. (1984). On the existence of an optimal capital structure: Theory and evidence. Journal of Finance, 39(3), 857-878. http://dx.doi.org/10.1111/j.1540-6261.1984.tb03680.x

De Angelo, H., \& Masulis, R. (1980). Optimal capital structure under corporate and personal taxation. Journal of Financial Economics, 8(1), 3-29. http://dx.doi.org/10.1016/0304-405X(80)90019-7

Donaldson, G. (1961). Corporate debt capacity: A study of corporate debt policy and the determination of corporate debt capacity. Boston: Division of Research, Harvard School of Business Administration.

Errunza, V. R. (1979). Efficiency and the Programmes to develop capital markets - The Brazilian Experience. Journal of Banking and Finance, 3, 355-382. http://dx.doi.org/10.1016/0378-4266(79)90028-1

Fama, E. F., \& French, K. (2002). Testing trade-off and pecking order Predictions about dividends and debt. Review of Financial Studies, 15(1), 1-33. http://dx.doi.org/10.1093/rfs/15.1.1

Guha-Khasnobis, B., \& Kar, S. (2006). The corporate debt market: A firm-level panel study for India. UNU-WIDER Research Paper 50.

Gul, F. A., \& Tsui, J. S. L. (1998). A test of the free cash flow and debt monitoring hypotheses: Evidence from audit pricing. Journal of Accounting and Economics, 24, 219-237. http://dx.doi.org/10.1016/S0165-4101(98)00006-8

Hamson, D. F. (1992). An empirical examination of corporate capital structure in Australia and the USA, (Unpublished PhD Thesis submitted in the Department of Commerce, University of Queensland, Australia).

Harris, M., \& Raviv, A. (1991). The theory of the capital structure. Journal of Finance, 46(1), 297-355.

Hart, O., \& Moore, J. (1988). Incomplete Contracts and Renegotiation. Econometrica, 56, 755-786. http://dx.doi.org/10.2307/1912698

Inanga, E. L., \& Ajayi, C. A. (1999). Accountancy. Lagos: The CIBN Press Limited.

Jensen, M. (1986). Agency costs of free cash flow, corporate finance and takeovers. American Economic Review, 76. http://dx.doi.org/10.1017/CBO9780511609435.005

Jensen, M. C., \& Meckling, W. H. (1976). Theory of the firm: Managerial behavior, agency costs and ownership structure. Journal of Financial Economics, 3(4), 303-360. http://dx.doi.org/10.1016/0304-405X(76)90025-8 
Kohler, H. (1994). Statistics for business and economics ( $3^{\text {rd }}$ ed.). New York: Harper Collins College Publishers.

Leland, H. (1994). Corporate debt value, Bond covenants, and optimal capital structure. Journal of Finance, 49(4), 1213-1252. http://dx.doi.org/10.1111/j.1540-6261.1994.tb02452.x

Miller, M. (1977). Debt and Taxes. Journal of Finance, 32(2), 261-275. http://dx.doi.org/10.1111/j.1540-6261.1977.tb03267.x

Modigliani, F., \& Miller, M. H. (1958). The cost of capital, corporate finance and the theory of investment. American Economic Review, 48, 261-297.

Modigliani, F., \& Miller, M. H. (1963). Corporate income taxes and the cost of capital: A correction. American Economic Review, 53(3), 433-443.

Myers, S. C. (1977). The Determinants of Corporate Borrowing. Journal of Financial Economics, 5, 147-175. http://dx.doi.org/10.1016/0304-405X(77)90015-0

Myers, S. C. (1984). The capital structure puzzle. Journal of Finance, 39(3), 574-592.

Myers, S. C., \& Majluf, N. (1984). Corporate financing and investment decisions when firms have information investors do not have. Journal of Financial Economics, 13(2), 187-221. http://dx.doi.org/10.1016/0304-405X(84)90023-0

Ozkan, A. (2001). Determinants of capital structure and adjustment to long run target: Evidence from UK company panel data. Journal of Business Finance and Accounting, 28(1-2), 175-198. http://dx.doi.org/10.1111/1468-5957.00370

Parrino, R., \& Weisbach, M. (1999). Measuring Investment Distortions arising from Stockholder- Bondholder Conflicts. Journal of Financial Economics, 53, 3-42. http://dx.doi.org/10.1016/S0304-405X(99)00015-X

Ross, S. A., Westerfield, R. W., \& Jaffe, J. (2002). Corporate Finance. USA: McGraw - Hill, 390.

Salawu, R. O. (2007). An empirical analysis of the capital structure of selected quoted companies in Nigeria. The International Journal of Applied Economic and Finance, 1, 16-28. http://dx.doi.org/10.3923/ijaef.2007.16.28

Salawu, R. O. (2007). The determinants of the capital structure of financial firms in Nigeria: The Financial Managers' Perspectives. Global Journal of Business Research, 1(1), 60-69.

Salawu, R. O., \& Agboola, A. A. (2008). The determinants of capital structure of large non-financial listed firms in Nigeria. The International Journal of Business and Finance Research, 2(2), 75-84.

Shyam-Sunder, L., \& Myers, S. C. (1999). Testing static tradeoff against pecking order models of capital $\begin{array}{lllll}\text { structure. Journal of } & \text { Financial } & \text { Economics, } & 51(2), & \text { 219-244. }\end{array}$ http://dx.doi.org/10.1016/S0304-405X(98)00051-8

Smith, C., \& Warner, J. (1979). On financial contracting: An analysis of bond covenants. Journal of Financial Economics, 7(2), 117-161. http://dx.doi.org/10.1016/0304-405X(79)90011-4

Timan, S., \& Wessels, R. (1988). The determinants of capital structure choice. Journal of Finance, 4(1), 1-19.

Warner, J. (1977). Bankruptcy costs: Some evidence. Journal of Finance, 32(2), 337-47.

Wippern, R. F. (1966). Financial structure and the value of the firm. Journal of Finance, 21(4), 615-633. http://dx.doi.org.10.1111/j.1540-6261.1966.tb00270.x 
Appendix I: List of Companies Sampled:

\begin{tabular}{|c|l|c|l|}
\hline S/N & \multicolumn{1}{|c|}{ Company } & S/N & \multicolumn{1}{|c|}{ Company } \\
\hline $\mathbf{1 .}$ & 7-up Bottling Co. Plc & $\mathbf{2 1 .}$ & Neimeth Inter. Pharm \\
\hline $\mathbf{2 .}$ & G Leventis Nig. plc. & $\mathbf{2 2 .}$ & Nestle Nig. plc. \\
\hline $\mathbf{3 .}$ & Academy Press & $\mathbf{2 3 .}$ & Nigeria-German Chem. Plc. \\
\hline $\mathbf{4 .}$ & Afprint Nig. Plc. & $\mathbf{2 4 .}$ & Nigerian Aviation Handling Co. \\
\hline $\mathbf{5 .}$ & African Paints (Nig.) Plc. & $\mathbf{2 5 .}$ & Nigerian Bag Manufacturing Co. \\
\hline $\mathbf{6 .}$ & African Pet. Plc. & $\mathbf{2 6 .}$ & Nigerian Ropes Plc. \\
\hline 7. & Ashaka Cement. Plc & $\mathbf{2 7 .}$ & Oando Plc. \\
\hline $\mathbf{8 .}$ & Benue Cement Comp. Plc. & $\mathbf{2 8 .}$ & Okomu Oil Palm Plc. \\
\hline $\mathbf{9 .}$ & Cadbury Nig. Plc. & $\mathbf{2 9 .}$ & P. S. Mandrides \& Co.Plc \\
\hline $\mathbf{1 0 .}$ & Cement Co. of North Nig. Plc. & $\mathbf{3 0 .}$ & Premier Paints Plc. \\
\hline $\mathbf{1 1 .}$ & Chellarams Plc. & $\mathbf{3 1 .}$ & Presco Plc. \\
\hline $\mathbf{1 2 .}$ & Conoil Plc. & $\mathbf{3 2 .}$ & SCOA Nig. Plc. \\
\hline $\mathbf{1 3 .}$ & Costain (WA) Plc. & $\mathbf{3 3 .}$ & Total Nig. Plc. \\
\hline $\mathbf{1 4 .}$ & Ellah lakes Plc. & $\mathbf{3 4 .}$ & Tripple Gee \& Comp. Plc. \\
\hline $\mathbf{1 5 .}$ & Eterna Oil \& Gas Plc. & $\mathbf{3 5 .}$ & UTC Nig. Plc. \\
\hline $\mathbf{1 6 .}$ & Flour Mills Nig. Plc. & $\mathbf{3 6 .}$ & UACN Plc. \\
\hline $\mathbf{1 7 .}$ & Japaul Oil \& Maritime Serv. & $\mathbf{3 7 .}$ & UACN Property Dev. \\
\hline $\mathbf{1 8 .}$ & John Holt Plc. & $\mathbf{3 8 . ~}$ & United Nig. Textiles Plc. \\
\hline $\mathbf{1 9 .}$ & May \& Baker Nig. Plc. & $\mathbf{3 9 .}$ & Vitafoam Nig. Plc. \\
\hline $\mathbf{2 0 .}$ & Morison Indust. Plc. & \\
\hline & & & \\
\hline
\end{tabular}

